\title{
EFFECT OF STRAIN HARDENING ON FATIGUE CRACK CLOSURE IN ALUMINUM ALLOY UNDER CONSTANT AMPLITUDE WITH SINGLE OVERLOAD
}

\author{
Nirpesh Vikram \\ BBDNIIT, Lucknow, India \\ E-mail: nirpesh.vikram@gmail.com \\ Raghuvir Kumar \\ BBDNIIT, Lucknow, India \\ E-mail: rkg@mnnit.ac.in \\ Submission: 08/06/2015 \\ Revision: $12 / 07 / 2015$ \\ Accept: 22/07/2015
}

\section{ABSTRACT}

In this study effect of strain hardening on crack closure has been examined with the help of experiments and finite element method on the side edge notched specimen of five different Aluminum alloy (3003 Al, 5052 Al, 6061 T6, 6063 T6, 6351) in mode I under constant amplitude fatigue loading with single overload using Abaqus ${ }^{\circledR} 6.10$ which is very well accepted FEM application in research. Extended

Finite Element Method Module has been used to determine effective stress intensity factor at the crack tip while propagation takes place. FEM results have given good agreement with experimental results. Regression analysis has also been done with SPSS ${ }^{\circledR} 16$ and dependency of strain hardening coefficient on crack closure has analyzed. A generalized empirical formula has been developed based on strain hardening to calculate effective stress intensity range ratio and a modified Paris law has also been formulated for these aluminum alloy.

Keywords: Fracture Mechanics, Strain Hardening, Abaqus ${ }^{\circledR}$, Fatigue, Crack Closure, SPSS ${ }^{\circledR}$ 
INDEPENDENT JOURNAL OF MANAGEMENT \& PRODUCTION (IJM\&P)

http://www.ijmp.jor.br

v. 6, n. 4, October - December 2015

ISSN: 2236-269X

DOI: 10.14807/ijmp.v6i4.342

\section{INTRODUCTION}

Failure of the components is the results of two reasons one is fatigue loading and other one is working environment like temperature that is the most common factor for environment affected failure (VIKRAM; RAGHUVIR, 2015). In real life mostly complex loading environment in which the components work but at the time of analysis whether it can be experimental, theoretical or numerical we consider the ideal loading environment to achieve the solutions easily. Fatigue is very common reason of crack initiation, propagation to critical size (VIKRAM; RAGHUVIR; KUMAR, 2014; BROEK, 1982) at which sudden fracture occurs.

Crack extension takes place due to high stress at the crack tip and due to plastics deformation at the crack tip during cyclic loading; many efforts have been made to relate the stress intensity range ratio with stress intensity factor " $\mathrm{K}$ " at the crack tip. A well-established formula was given which is shown in "equation (1)" by Paris and Erdogan (NICCOLLS, 1976).

$$
\frac{d a}{d N}=C(\Delta K)^{n}
$$

Where "C" and " $\mathrm{C}$ " are material property coefficients. It is realized that for different values of stress ratios, $R$, for a material a large deviation was obtained in data from the curve fitted by "equation (1)". The range of cyclic stress intensity factors for describing fatigue crack growth rate (FCGR) is based on the assumption that the crack tip starts opening as soon as load is completely relaxed.

Elber (ASTM, 1967; PARIS; ERDOGAN, 1963; WALKER, 1970; BROEK, 1982) studied that cyclic plasticity gives rise to the formation of residual plastic deformation in the wake of the crack tip causing the fatigue load crack to close and presented this as crack closure phenomenon and advised that the fatigue crack growth can take place only during the portion of the loading cycle in which the crack is fully open. Based on this suggestion, effective stress range is defined as:

$$
\triangle \sigma_{\text {eff }}=\sigma_{\mathrm{m}}-\sigma_{\circ}\left(\text { or } \sigma_{\mathrm{cl}}\right)
$$

The ratio of $\triangle \sigma_{\text {eff }}$ to the total stress range $(\triangle \sigma)$ is known as the stress intensity range ratio, $U$, and is shown by

$$
\mathrm{U}=\frac{\Delta \sigma_{\mathrm{ar}}}{\Delta \nabla}=\frac{\sigma_{\mathrm{m}}-\sigma_{\mathrm{g}}\left(\mathrm{or} \mathrm{\sigma}_{\mathrm{s}}\right)}{\sigma_{\mathrm{m}}-\sigma_{\mathrm{n}}}
$$


Elber (VIKRAM; KUMAR, 2013) further advised that the crack growth can be written in the following form:

$$
\frac{d e}{d N F}=C\left(\Delta K_{e f f}\right)^{n}=C(U \Delta K)^{n}
$$

In the crack propagation equation " $\Delta \mathrm{K}$ " replaced by " $\Delta K_{o f f}$, the factors which influence $U$ are stress intensity range $(\triangle \sigma)$, material properties $\left(\sigma_{y}, \sigma_{f}\right)$, crack length (a) and stress ratio R. Elber (VIKRAM; KUMAR, 2013), showed that U depends only on stress ratio $\mathrm{R}$. So many laws are available which give crack growth rate as a function of $\triangle K$ and material properties. Many other researchers (ASTM, 1967; PARIS; ERDOGAN, 1963; FOREMAN; MEARNEY; ENGLE, 1967; VIKRAM; KUMAR, 2013; VIKRAM; RAGHUVIR; KUMAR, 2014; VIKRAM; RAGHUVIR, 2015; KUMAR; GARG, 1988; PEARSON, 1972; OSGOOD, 1982; ZHENG, 1983) had also given their contribution to formulate the crack growth and crack closure. In the present study, effort has been made on side edge notched specimen (SEN) to show the effect of strain hardening on crack closure and form an empirical relationship for aluminum alloys 3003, 5052, 6061, 6063, 6351.

\section{MATERIALS AND SPECIMEN GEOMETRY ANALYZED}

\subsection{Material properties:}

Five Aluminum Alloy have been used to prepare specimens are $3003 \mathrm{Al}, 5052$ $\mathrm{Al}, 6061-\mathrm{T} 6 \mathrm{Al}, 6063-\mathrm{T} 6 \mathrm{Al}, 6351 \mathrm{Al}$ that's chemical and mechanical properties are given in Table no. 1 and 2 respectively.

Table 1: Chemical composition

\begin{tabular}{|c|c|c|c|c|c|c|c|c|c|}
\hline \multirow[b]{2}{*}{ Material } & \multicolumn{9}{|c|}{ Element } \\
\hline & & & & & & & & & \\
\hline & $\mathrm{Si}$ & $\mathrm{Fe}$ & $\mathrm{Cu}$ & $\mathrm{Mn}$ & $\mathrm{Mg}$ & $\mathrm{Cr}$ & $\mathrm{Zn}$ & $\mathrm{Ti}$ & other \\
\hline $\begin{array}{ll}6061 & \text { T6 } \\
\mathrm{Al} & \\
\end{array}$ & $\begin{array}{l}0.4- \\
0.8 \\
\end{array}$ & 0.7 & $\begin{array}{l}0.15- \\
0.40\end{array}$ & 0.15 & $\begin{array}{l}0.8- \\
1.2\end{array}$ & $\begin{array}{l}0.04- \\
0.35\end{array}$ & 0.25 & 0.15 & 0.4 \\
\hline $\begin{array}{l}6063 \\
\mathrm{Al}\end{array}$ & $\begin{array}{l}0.30- \\
0.70 \\
\end{array}$ & 0.6 & 0.1 & 0.3 & $\begin{array}{l}0.40- \\
0.90 \\
\end{array}$ & & & & 0.4 \\
\hline $6351 \mathrm{Al}$ & $\begin{array}{l}0.7- \\
1.3 \\
\end{array}$ & 0.5 & 0.1 & $\begin{array}{l}0.4- \\
0.8 \\
\end{array}$ & $\begin{array}{l}0.4- \\
0.8 \\
\end{array}$ & & 0.2 & 0.2 & \\
\hline $3003 \mathrm{Al}$ & 0.6 & 0.7 & $\begin{array}{l}0.05- \\
0.20\end{array}$ & $\begin{array}{l}1.0- \\
1.5 \\
\end{array}$ & & & 0.1 & & \\
\hline $5052 \mathrm{Al}$ & 0.25 & 0.4 & 0.1 & 0.1 & $\begin{array}{l}2.2- \\
2.8\end{array}$ & $\begin{array}{l}0.15- \\
0.35\end{array}$ & 0.1 & & - \\
\hline
\end{tabular}


Table 2: Physical properties

\begin{tabular}{|c|c|c|c|c|c|c|}
\hline \multirow[b]{2}{*}{ Material } & \multicolumn{6}{|c|}{ Element } \\
\hline & $\sigma_{\mathrm{y}}$ & $\sigma_{\mathrm{u}}$ & $\sigma_{\mathrm{f}}$ & Ex10 $0^{6}$ & Elongation \% & $\begin{array}{l}\text { Reduction } \\
\text { in Area } \\
\%\end{array}$ \\
\hline $\begin{array}{l}6061 \mathrm{T6} \\
\mathrm{Al}\end{array}$ & 30.14 & 32.5 & 45 & 7 & 10.5 & 28.3 \\
\hline $\begin{array}{l}6063 \mathrm{~T} 6 \\
\mathrm{Al} \\
\end{array}$ & 21 & 24.2 & 64 & 7 & 10.6 & 60 \\
\hline $6351 \mathrm{Al}$ & 174.7 & 179.31 & 129.3 & 14.76 & 17 & 50 \\
\hline $3003 \mathrm{Al}$ & 153 & 157 & 8 & 16 & 8 & 18.7 \\
\hline $5052 \mathrm{Al}$ & 195 & 230 & 105 & & 32 & \\
\hline
\end{tabular}

\subsection{Specimen Geometry:}

Side edge notched Specimen has been modeled with the dimensions as below

Length (H)- $180 \mathrm{~mm}$

Width (W) - $50 \mathrm{~mm}$

Thickness (t) $-3 \mathrm{~mm}$

Initially a notch of $6 \mathrm{~mm}$ had been made at en edge for crack propagation under the load applications on the specimen during the fatigue test. The geometry is shown in Figure 1.

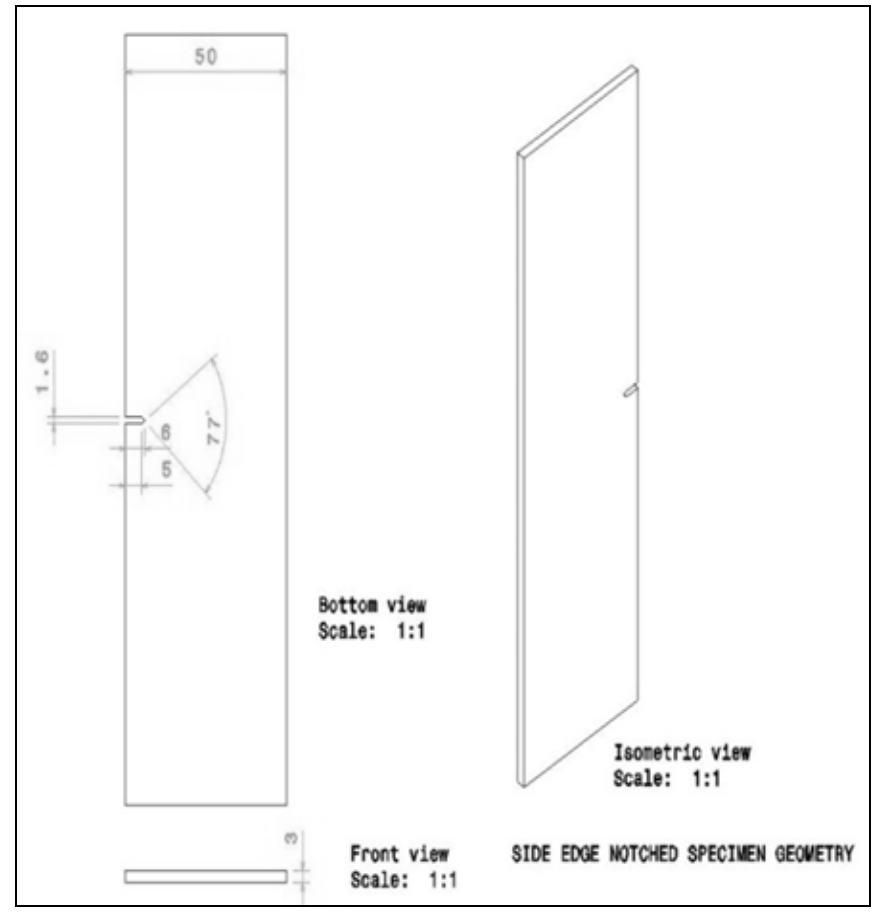

Figure 1: Specimen Geometry 
INDEPENDENT JOURNAL OF MANAGEMENT \& PRODUCTION (IJM\&P)

http://www.ijmp.jor.br

v. 6, n. 4, October - December 2015

ISSN: 2236-269X

DOI: 10.14807/ijmp.v6i4.342

\section{METHODOLOGY}

The methodology adopted for this study has certain specific steps which start from experiments for fatigue testing of the specimen given in Figure 1 on MTS machine and result data collected for the validation with finite element method and tabulated all result parameters together to perform regression analysis to determine the dependency of strain hardening on fatigue crack closure. All steps are shown in Figure 2.

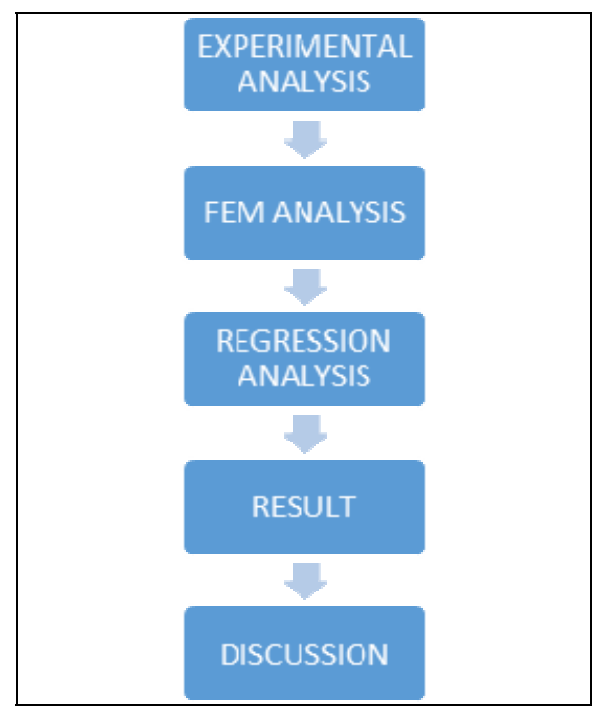

Figure 2: Flow Diagram of Methodology

\section{FINITE ELEMENT ANALYSIS OF CRACK}

\subsection{D modeling using Catia V5 R19:}

3D modeling of specimen had been done on CATIA V5 R19 as shown in Fig: 01 the dimensions of the specimen were based on ASTM standard E399 for fatigue testing and then it has been imported to Abaqus $^{\circledR} 6.10$ as a deformable solid part and analyzed to determine various parameters during crack propagation.

\subsection{FEM Modeling}

A crack had been developed in Abaqus ${ }^{\circledR} 6.10$ itself as a shell deformable part. After modeling both the instances were called in assemble module to insert the crack in the specimen. C3D8R elements were used to mesh the specimen but not the crack. Crack remains unmeshed throughout the analysis.

Because the whole analysis were done for Mode I as Figure 2 so that one side of the specimen were kept fixed and other end was loaded. XFEM module was used to study the onset and propagation of cracking in quasi-static problems. XFEM 
allows us to study crack growth along an arbitrary, solution-dependent path without needing to remesh our model. We can choose to study a crack that grows arbitrarily through our model or a stationary crack.

We defined an XFEM crack in the Interaction module. We specified the initial location of the crack. Alternatively, we allowed Abaqus $^{\circledR}$ to determine the location of the crack during the analysis based on the value of the maximum principal stress or strain calculated in the crack domain.

\subsection{Initial Conditions}

Initial values of stresses, temperatures, field variables, solution-dependent state variables, etc. specified as follows.

\subsection{Boundary Conditions}

Specimen has been kept in mode I fracture mode that is called as crack opening mode as shown in Figure 3 in this mode tensile forces are exerted on the top and bottom face of the specimen in this case displacement will be normal to the crack surface.

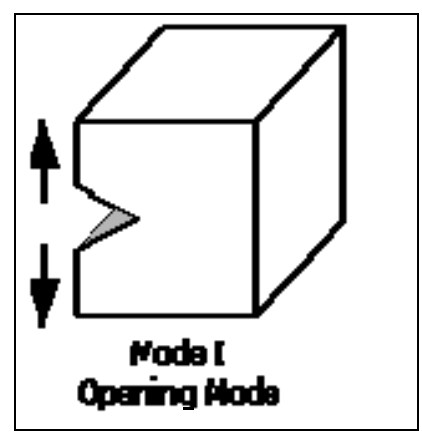

Figure 3: Mode I Fracture Modes

Boundary conditions applied to the displacement and rotation degrees of freedom for the SEN Specimen. One side kept fixed (use Encastre Boundary condition) and on other side stress applied. During the analysis, boundary conditions had an amplitude definition that is cyclic over the step.

\subsection{Loads}

Following loading conditions were considered:

- Case $1: P_{\min }=0 \mathrm{kN} ; P_{\max }=6.2 \mathrm{kN} ; \mathrm{R}=0 ; \mathrm{OLR}=1.0$

- Case2: $P_{\min }=0 \mathrm{kN} ; P_{\max }=6.2 \mathrm{kN} ; R=0 ; O L R=1.5$

- Case $: P_{\min }=0 k N ; P_{\max }=6.2 k N ; R=0 ; O L R=1.8$ 
INDEPENDENT JOURNAL OF MANAGEMENT \& PRODUCTION (IJM\&P)

http://www.ijmp.jor.br

v. 6, n. 4, October - December 2015

ISSN: 2236-269X

DOI: $10.14807 /$ ijmp.v6i4.342

- Case $4: P_{\min }=0 k N ; P_{\max }=6.2 k N ; R=0 ; O L R=2.0$

\subsection{Fields Output}

Fields output variables 'PHILSM', 'PSILSM' and STATUSXFEM under the Failure/Fracture and Status category respectively are selected to calculate crack length with no of load cycle.

\subsection{Result visualization}

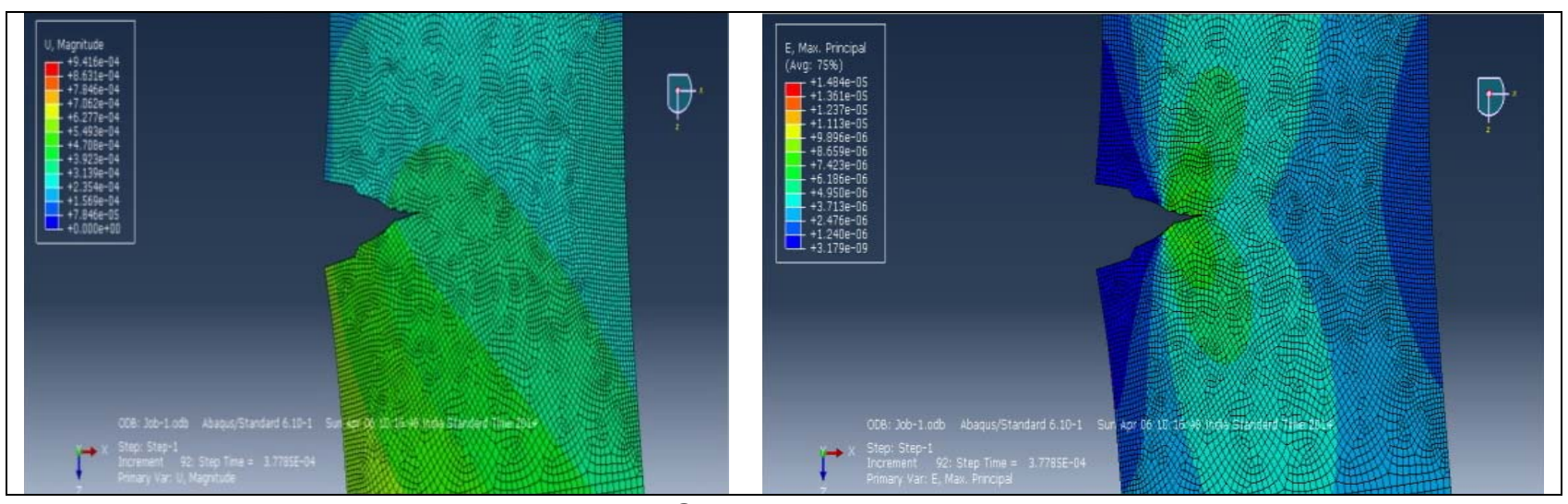

Figure 4: Crack Propagation

\section{REGRESSION ANALYSIS:}

After FEM analysis, Linear Regression analysis was done on SPSS ${ }^{\circledR}$ 16. From the output we have drawn the graphs between $U$ Vs. $n$ fitted the trend line and got coefficients value for trend line equation for each material. After getting equation for each material we formed a generalized equation that suits the result of all five aluminum alloys and with the help of this we can predict the approximation for crack closure of other Aluminum alloys too. The scheme of the curves is shown below.

Coefficients (For $3003 \mathrm{Al}$ )

\begin{tabular}{|c|c|c|c|c|c|}
\hline \multirow{2}{*}{} & \multicolumn{2}{|c|}{ Unstandardized Coefficients } & Standardized Coefficients & \multirow{2}{*}{ T } & Sig. \\
\cline { 2 - 5 } & $\mathrm{B}$ & Std. Error & Beta & .350 & 0.000 \\
\hline $\mathrm{n}$ & 0.01 & 0.003 & 0.074 & 86.9 & 0.000 \\
\hline
\end{tabular}

Coefficients (For $6061 \mathrm{Al}$ )

\begin{tabular}{|l|r|r|r|r|r|}
\hline \multirow{2}{*}{} & \multicolumn{2}{|c|}{$\begin{array}{c}\text { Unstandardized } \\
\text { Coefficients }\end{array}$} & $\begin{array}{c}\text { Standardized } \\
\text { Coefficients }\end{array}$ & \multirow{2}{*}{ T } & \multirow{2}{*}{ Sig. } \\
\cline { 2 - 4 } & \multicolumn{1}{|c|}{ B } & Std. Error & Beta & \multicolumn{1}{c|}{ T } \\
\cline { 2 - 5 } N & 0.803 & 0.004 & 0.015 & 0.092 & 0.000 \\
(Constant) & 0.824 & 0.001 & & 70.223 & 0.092 \\
\hline
\end{tabular}




\section{Coefficients (For 5052 Al)}

\begin{tabular}{|l|r|r|r|r|r|}
\hline \multirow{2}{*}{} & \multicolumn{2}{|c|}{$\begin{array}{c}\text { Unstandardized } \\
\text { Coefficients }\end{array}$} & $\begin{array}{c}\text { Standardized } \\
\text { Coefficients }\end{array}$ & & \multirow{2}{*}{ T } \\
\cline { 2 - 4 } & \multicolumn{1}{|c|}{ B } & Std. Error & \multicolumn{1}{|c|}{ Beta } & \multicolumn{1}{c|}{ S } \\
\hline N & 0.207 & 0.015 & 0.001 & 0.003 & 0.000 \\
(Constant) & 0.798 & 0.048 & & 10.753 & 0.000 \\
\hline
\end{tabular}

Coefficients (For $6063 \mathrm{Al}$ )

\begin{tabular}{|c|c|c|c|c|c|}
\hline \multirow{2}{*}{} & \multicolumn{2}{|c|}{ Unstandardized Coefficients } & Standardized Coefficients & \multirow{2}{*}{ Sig. } \\
\cline { 2 - 5 } & B & Std. Error & Beta & & \\
\hline $\mathrm{N}$ & 0.960 & 0.001 & 0.096 & 0.612 & 0.000 \\
(Constant) & 0.176 & 0.002 & & 380.804 & 0.000 \\
\hline
\end{tabular}

Coefficients (For $6351 \mathrm{Al}$ )

\begin{tabular}{|l|r|r|r|r|r|}
\hline \multirow{2}{*}{} & \multicolumn{2}{|c|}{$\begin{array}{c}\text { Unstandardized } \\
\text { Coefficients }\end{array}$} & $\begin{array}{c}\text { Standardized } \\
\text { Coefficients }\end{array}$ & & \\
\cline { 2 - 4 } & \multicolumn{1}{|c|}{$\mathrm{B}$} & Std. Error & Beta & T & Sig. \\
\hline $\mathrm{N}$ & 0.021 & 0.000 & 0.121 & 0.313 & 0.000 \\
(Constant) & 0.777 & 0.001 & & 53.4 & 0.000 \\
\hline
\end{tabular}

Table 3: List of equations obtained after regression analysis

\begin{tabular}{|c|c|}
\hline Material & $\begin{array}{c}\text { Equations after } \\
\text { Regression Analysis }\end{array}$ \\
\hline $3003 \mathrm{Al}$ & $\mathrm{U}=0.160^{*} \mathrm{n}+0.973$ \\
\hline $6061 \mathrm{T6} \mathrm{Al}$ & $\mathrm{U}=0.207^{*} \mathrm{n}+0.824$ \\
\hline $5052 \mathrm{Al}$ & $\mathrm{U}=0.397^{*} \mathrm{n}+0.198$ \\
\hline $6063 \mathrm{T6} \mathrm{Al}$ & $\mathrm{U}=0.415^{*} \mathrm{n}+0.136$ \\
\hline $6351 \mathrm{Al}$ & $\mathrm{U}=0.220^{*} \mathrm{n}+0.777$ \\
\hline
\end{tabular}

\section{GENERALIZED RESULTS}

With the help of these equations we can form a generalized equation

$$
\text { i.e. } \quad U=0.22 * n+0.77
$$

\subsection{Validation of the Generalized Equation:}


DOI: $10.14807 /$ ijmp.v6i4.342

Table 4: Variation Check for $n=3.3$ (Value of $n$ is taken as arbitrary)

\begin{tabular}{|c|c|c|c|}
\hline Material & $\begin{array}{c}\mathbf{U} \text { (by } \\
\text { generalized } \\
\text { Equation) } \\
\text { For } \mathbf{n = 3 . 3}\end{array}$ & $\begin{array}{c}\mathbf{U}(\text { by } \\
\text { individual } \\
\text { equation) } \\
\text { For } \mathbf{n = 3 . 3}\end{array}$ & $\begin{array}{c}\text { Variation } \\
\mathbf{( \% )}\end{array}$ \\
\hline $3003 \mathrm{Al}$ & 1.503 & 1.501 & 1.397 \\
\hline $5052 \mathrm{Al}$ & 1.503 & 1.507 & 1.803 \\
\hline $6061 \mathrm{T6} \mathrm{Al}$ & 1.503 & 1.508 & 1.870 \\
\hline $6063 \mathrm{T6} \mathrm{Al}$ & 1.503 & 1.505 & 1.703 \\
\hline $6351 \mathrm{Al}$ & 1.503 & 1.503 & 1.530 \\
\hline
\end{tabular}

\section{MODIFIED PARIS LAW:}

Putting the above relationship between $U$ and $n$ in the Paris law modified Paris Relationship was formed which gives approximate $2 \%$ variation while calculating no. of cycles to failure which is very well suitable for aluminum alloy

$$
\mathrm{da} / \mathrm{d} N=\boldsymbol{C}\{(0.22 * \mathbf{n}+0.77) \Delta \mathrm{K}\}^{n}
$$

\section{CONCLUSION}

A plane stress analysis using XFEM and thereafter regression analysis at different stress range ratio were performed on side edge notched specimen and effect of strain hardening on crack closure were noticed that the value of effective stress intensity range ratio $(U)$ increases with the increasing strain hardening exponent at the crack tip. A generalized relationship was formed for evaluation of $U$ accordingly a modified Paris relationship was obtained.

\section{REFERENCES}

ASTM (1976) "Standard Definition of terms Relating to Fatigue Testing \& Statistical Analysis of Data ", ASTM STP, n. 595, p 61-77.

BROEK, D. (1982) Elementary Engg. Fracture Mechanics, Martinus Nijhoff Publishers, London, 1982.

ELBER, W. (1970) Fatigue Crack Closure-Under Cyclic Tension, Engg. Fracture Mechanics, n. 2, p. 37-45.

ELBER, W. (1971) The Significance of Fatigue Crack Closure, ASTM, n. 486, p. 230-242.

FOREMAN, R. G.; MEARNEY, V. E.; ENGLE, R. M. (1967) Numerical Analysis of Crack Propagation in Cyclic Loaded Structures, J. I. Basic Engg., Trans. ASME, n. 89 , p. 454. 
INDEPENDENT JOURNAL OF MANAGEMENT \& PRODUCTION (IJM\&P)

http://www.ijmp.jor.br

v. 6, n. 4, October - December 2015

ISSN: 2236-269X

DOI: 10.14807/ijmp.v6i4.342

KUMAR, R.; GARG, S. B. L. (1988a) Effect of Stress Ratio on Effective Stress Ratio \&Crack Growth in 6061-T6 Aluminium Alloy, Int. J., Pres. Ves. and piping.

KUMAR, R.; GARG, S. B. L. (1988) Study of Crack Closure Under Constant Amplitude Loading for 6063-T6 Aluminium Alloy, Int. J. Press. Ves.and piping.

NICCOLLS, E. H. (1976) A Co-relation for Fatigue Crack Growth Rate, ScriptaMetall, n. 10, p. 295-298.

OSGOOD, C. C. (1982) Fatigue Design Cranbury, New Jersey, U.S.A., Pergamon Press.

PANDEY, A. K. (1988) Effect of Load Parameters on Crack Growth Rate \& Fatigue Life, M.E. thesis, Allahabad.

PARIS, P. C.; ERDOGAN, F. (1963) A Critical Analysis of Crack Propagation Laws,

Trans. ASME J. Basic Engg. n. 55, p. 528-534.

PEARSON, S. (1972) Effect of Mean Stress in Aluminum Alloy in High \& low Fracture Toughness, Engg. Fracture Mechanics, n. 4, p. 9-24.

VIKRAM, N.; AGRAWAL, S.; KUMAR, R. (2014) Effect of Strain Hardening on Fatigue Crack Growth in5052 Al Alloy for Constant Amplitude Loading, SYLWAN., v. 158, n. 6 , p. $110-124$.

VIKRAM, N.; KUMAR, R. (2013) Review on Fatigue Crack Growth and Finite Element Method. IJSER, v. 4 n. 4, p. 833-842.

VIKRAM, N.; KUMAR, R. (2015) Effect of Strain Hardening On Fatigue Crack Closure In Aluminum Alloy, Int. J. Engg. Res. \& Sci. \& Tech, v. 4, n. 3.WALKER, K. (1970) The Effect of Stress Ratio During Crack Propagation \& Fatigue for 2024-T3 and 7075-T6 aluminium, ASTM STP, n. 462, p. 1-14.

ZHENG, X. (1983) Fatigue Crack Propagation in Steels, Engg. Fracture Mechanics, n. 18, p. 965-973.

ASTM (1967), Recommended Practice for Plane Strain Fracture Toughness Testing of High strength Metallic Materials Using a Fatigue Cracked Bend Specimen, TRP prepared by ASTM committee E-24. 
DOI: 10.14807/ijmp.v6i4.342

\section{APPENDIX A: RESULT VISUALALIZATION}

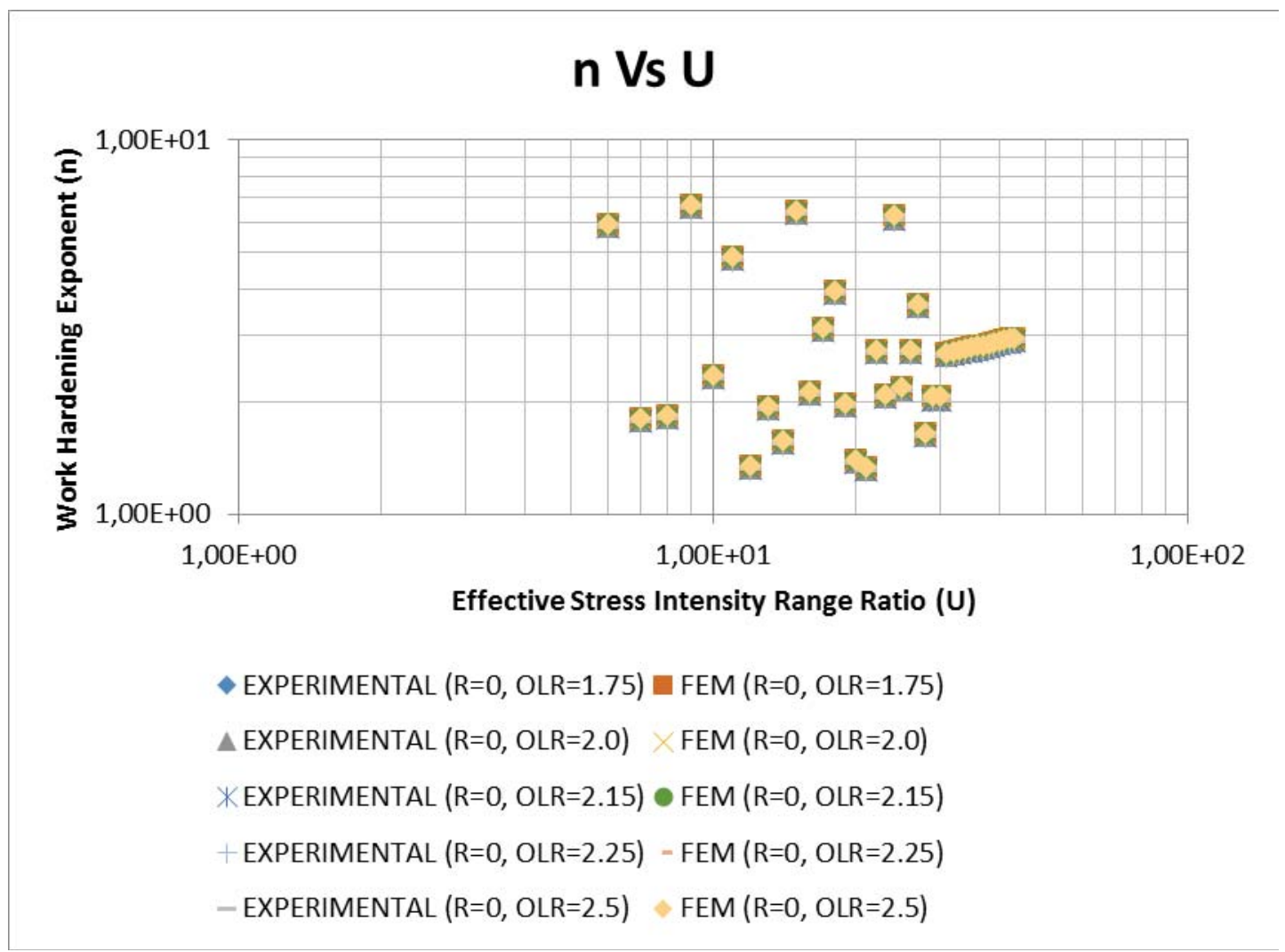

$3003 \mathrm{Al}$

\section{U Vs n}

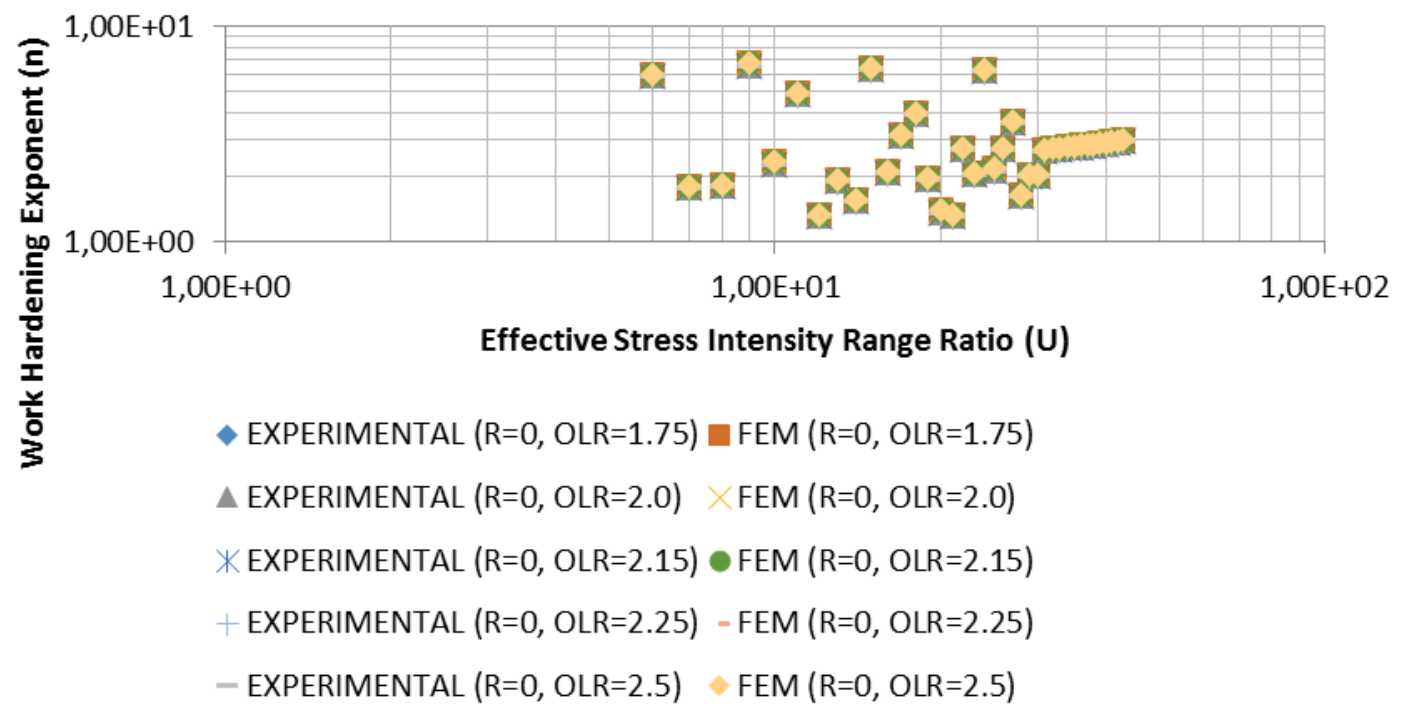

5052 Al 
INDEPENDENT JOURNAL OF MANAGEMENT \& PRODUCTION (IJM\&P)

http://www.ijmp.jor.br

v. 6, n. 4, October - December 2015

ISSN: 2236-269X

DOI: 10.14807/ijmp.v6i4.342

\section{n Vs U}

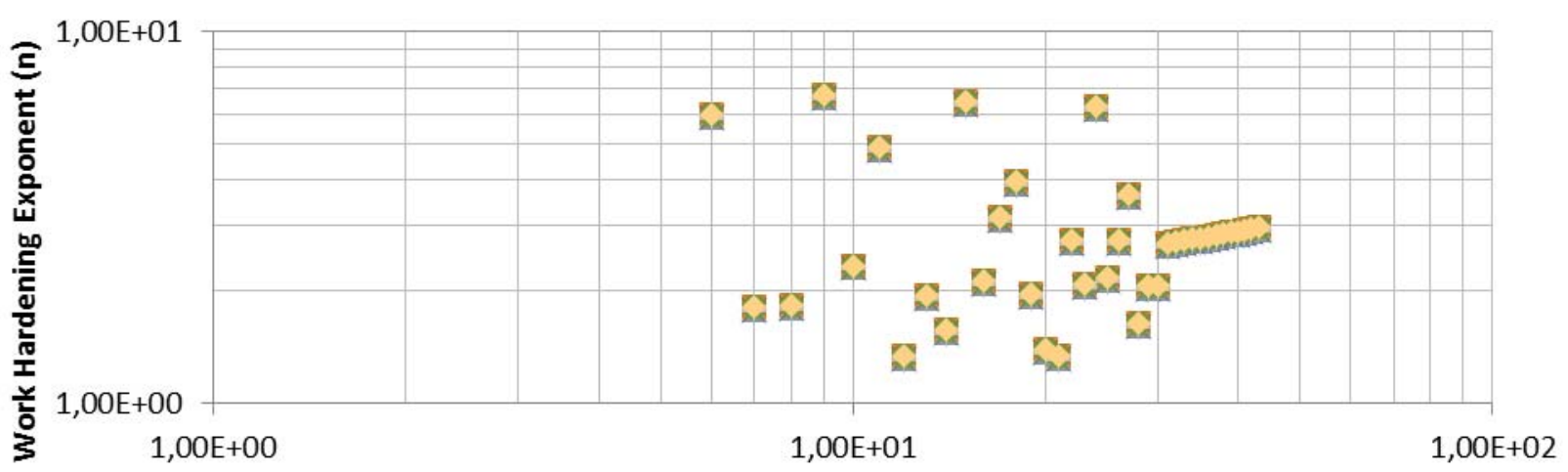

Effective Stress Intensity Range Ratio (U)

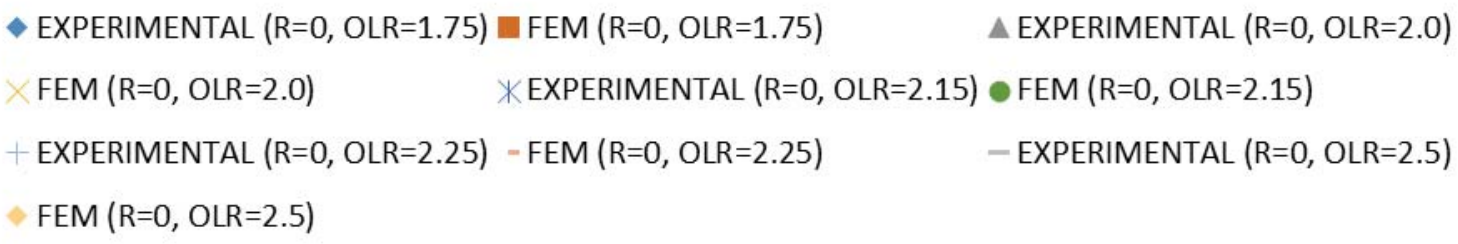

\section{$6061 \mathrm{Al}$}

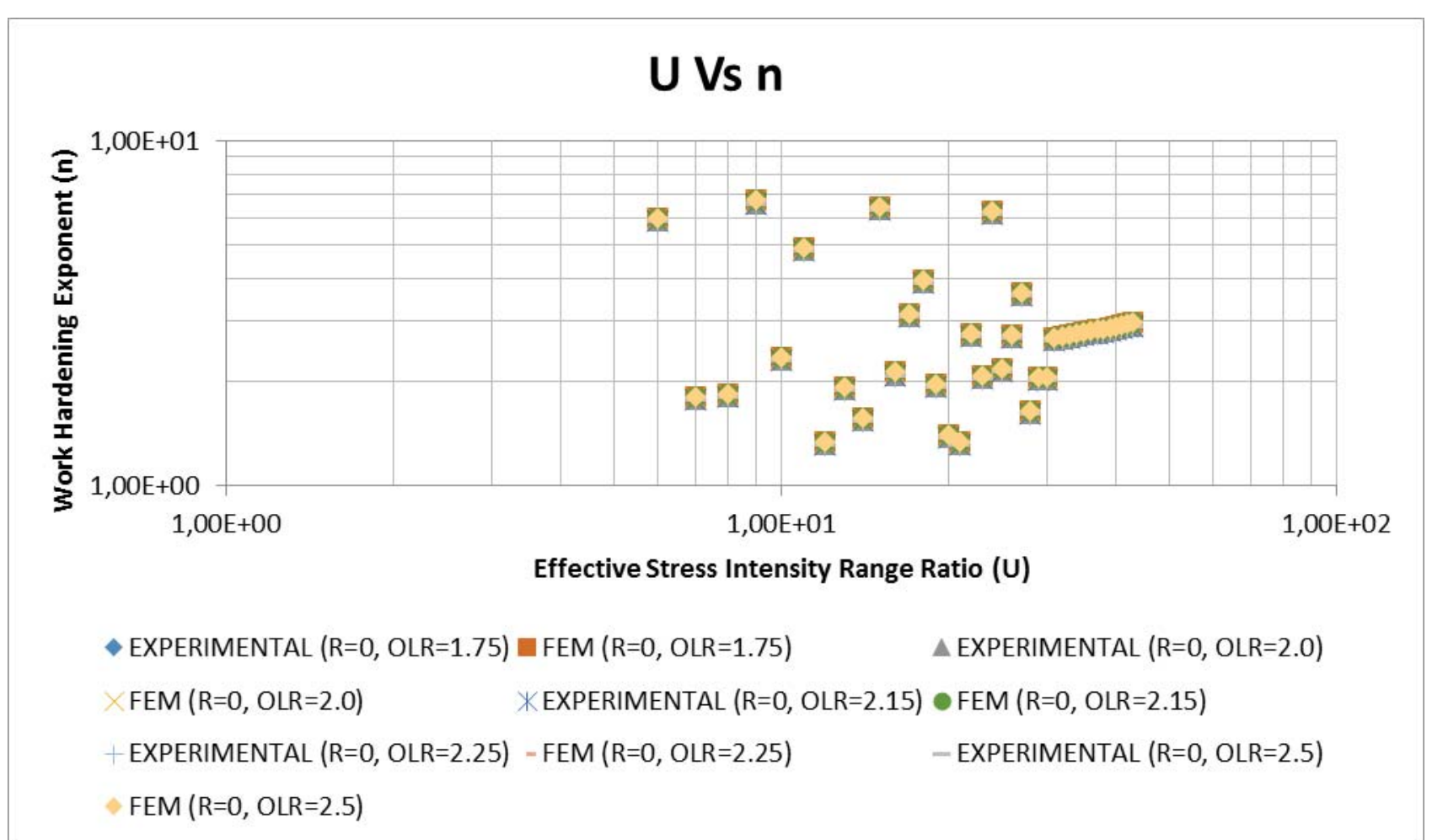

$6063 \mathrm{Al}$ 
ISSN: 2236-269X

DOI: 10.14807/ijmp.v6i4.342

\section{U Vs n}

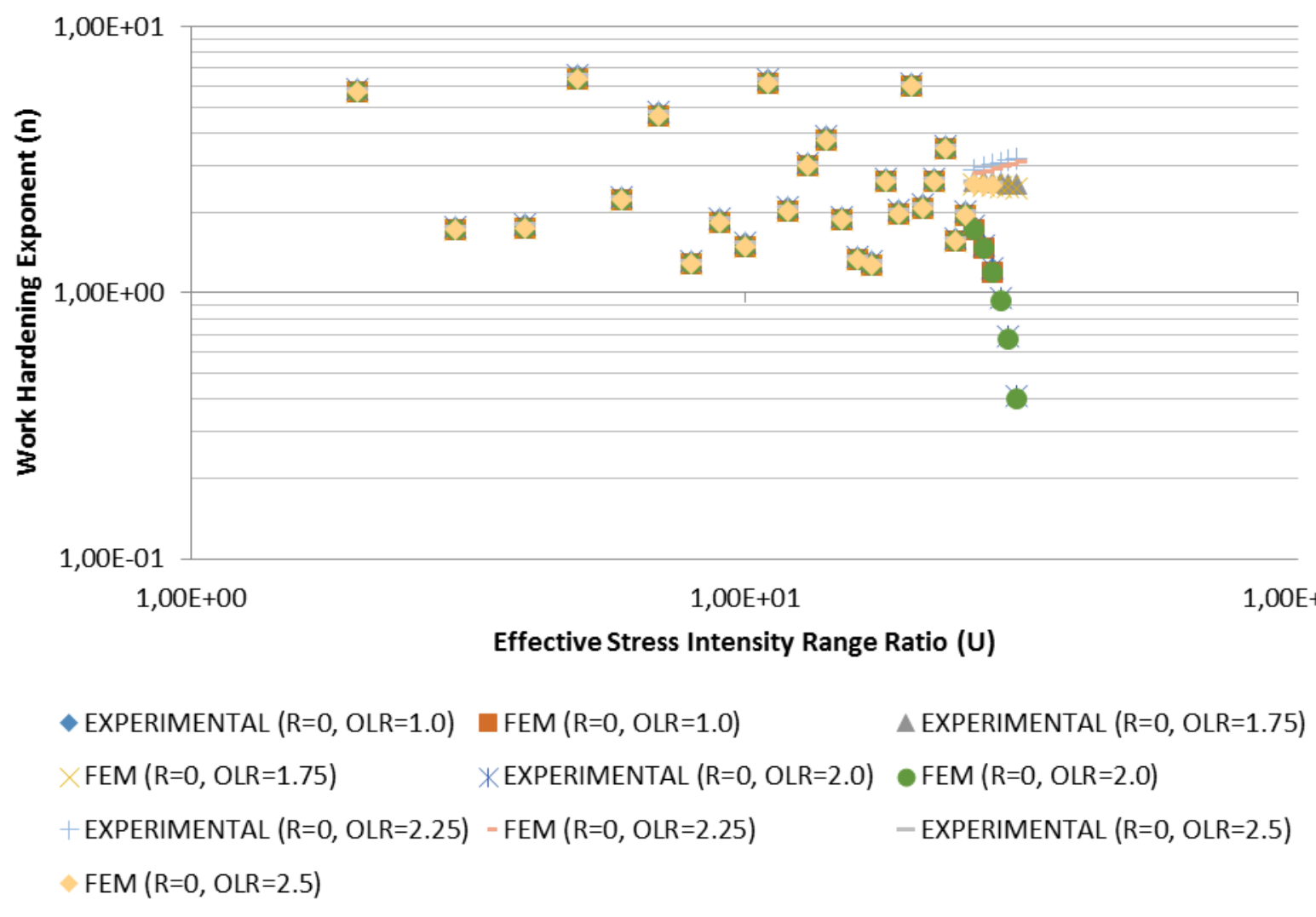

$6351 \mathrm{Al}$ 
APPENDIX B: NOMENCLATURE

\section{GREEK SYMBOLS}

$\alpha$

$\sigma$

$\sigma_{\mathrm{a}}$

$\sigma_{\mathrm{m}}$

$\sigma_{\mathrm{n}}$

$\sigma_{\mathrm{o}}$

$\sigma_{\mathrm{p}}$

$\sigma_{u}$

$\sigma_{\mathrm{y}}$

$\Delta \sigma$

ENGLISH SYMBOLS

a

$\mathrm{C}$

$\frac{d a}{w N}$

E

K

$\Delta \mathrm{K}$

$\mathrm{m}$

n

$N$

$N_{f}$

$\mathrm{P}$

$\mathrm{P}_{\mathrm{m}}$

$\mathrm{P}_{\mathrm{n}}$

$\Delta \mathrm{P}$

$\mathrm{R}$

W

\section{DESCRIPTION}

A variable factor

Normal stress

Average (mean) stress in a cycle

Maximum stress in a cycle

Minimum stress in a cycle

Optimum stress

Stress amplitude in a cycle

Ultimate stress

Yield stress

Stress range

\section{DESCRIPTION}

Crack length

Constant of crack growth equation

Crack growth rate

Young's modulus of elasticity

Stress intensity factor

Stress intensity range

Exponent of crack growth rate equation

Exponent of crack growth rate equation

Number of cycles

Number of cycles to failure

Simple load

Maximum load in a cycle

Minimum load in a cycle

Load range in a CAL cycle

Stress ratio in CAL cycle $\left({ }_{P_{n}}^{P_{m}}\right)$

Width of the specimen 